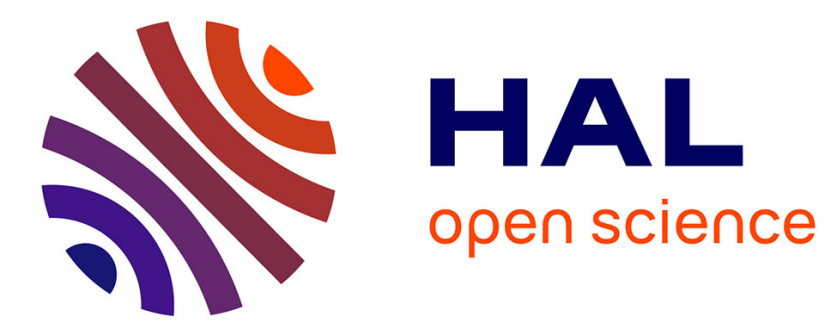

\title{
The terrestrialization process: A palaeobotanical and palynological perspective
}

Brigitte Meyer-Berthaud, Thomas Servais, Marco Vecoli, Philippe Gerrienne

\section{To cite this version:}

Brigitte Meyer-Berthaud, Thomas Servais, Marco Vecoli, Philippe Gerrienne. The terrestrialization process: A palaeobotanical and palynological perspective. Review of Palaeobotany and Palynology, 2016, The terrestrialization process : a palaeobotanical and palynological perspective - volume 1, 224 (1), pp.1-3. 10.1016/j.revpalbo.2015.10.011 . hal-01278369

\section{HAL Id: hal-01278369 \\ https://hal-sde.archives-ouvertes.fr/hal-01278369}

Submitted on 26 Nov 2020

HAL is a multi-disciplinary open access archive for the deposit and dissemination of scientific research documents, whether they are published or not. The documents may come from teaching and research institutions in France or abroad, or from public or private research centers.
L'archive ouverte pluridisciplinaire HAL, est destinée au dépôt et à la diffusion de documents scientifiques de niveau recherche, publiés ou non, émanant des établissements d'enseignement et de recherche français ou étrangers, des laboratoires publics ou privés. 


\title{
The terrestrialization process: A palaeobotanical and palynological perspective
}

\author{
Brigitte Meyer-Berthaud $^{\mathrm{a}, *}$, Thomas Servais ${ }^{\mathrm{b}}$, Marco Vecoli ${ }^{\mathrm{c}}$, Philippe Gerrienne ${ }^{\mathrm{d}}$ \\ a CNRS, Université de Montpellier, Botanique et modélisation de l'architecture des plantes et des végétations (AMAP), F-34098 Montpellier, France \\ ${ }^{\mathrm{b}}$ Evo-Eco-Paléo, UMR 8198 du CNRS, Université de Lille, F-59655 Villeneuve d'Ascq, France \\ c Biostratigraphy Group, Exploration Technical Services Department, Saudi Aramco, Dhahran, Saudi Arabia \\ d PPP, Département de Géologie, Université de Liège, Allée du 6 Août, B18 Sart Tilman, B4000 Liège, Belgium
}

\section{A R T I C L E I N F O}

\section{Article history:}

Received 30 October 2015

Accepted 30 October 2015

Available online 1 November 2015

Early studies on the origin of land plants, or embryophytes, were linked to the debate between Bower's antithetic and Scott's homologous theories regarding the alternation of generations in land plants, and more specifically the origin of the sporophyte generation (Haig, 2008; Qiu et al., 2012). The great progresses in phylogenetic studies and the advent of molecular analyses in the last fifty years unambiguously showed that land plants derive from a group of haplobiontic algae with a dominant haploid phase. Embryophytes are monophyletic, and the bryophytes s. l. (liverworts, mosses, hornworts) represent the most basal groups known to date. However, when considering extant plants only, there is a large morphological gap between the algal groups resolved as the cradle of the land plants, and the bryophytes. If the advances in molecular phylogeny have provided a helpful framework for predicting the morphology of the earliest embryophytes, the questions of when they originated, how their sporophytes, gametophytes and spores actually looked like, and how fast and extensively they diversified can be answered only by palynological and palaeobotanical analyses (Taylor and Strother, 2009; Kenrick et al., 2012). More precisely, as the record of spores and cryptospores produced by land plants long predates the appearance of macroscopic remains in the sediments, the palynological record is actually the only source of information documenting the very earliest stages of the terrestrialization of plants (Wellman, 2010).

The application of quantitative methods in the fields of geobiology and palaeoclimatology during the last 30 years resulted in the elaboration of complex models, accounting for the tight links between life (especially land plants), geochemical cycles, Earth surface conditions, and climate (e.g. Donnadieu et al., 2004; Beerling and Berner, 2005; Berner, 2006; Goddéris et al., 2014). For the Palaeozoic, these models

\footnotetext{
* Corresponding author.

E-mail address: meyerberthaud@cirad.fr (B. Meyer-Berthaud).
}

have been applied to the understanding of the relationships among major events such as the onset and demise of extensive glaciations, significant changes in the concentration of chemical elements in the oceanic and atmospheric reservoirs, evolution and radiations of major groups of organisms. However, if mechanisms of interactions are becoming better understood, there is still a need for a more comprehensive and detailed description of each specific event from a geological and palaeobiological point of view. For this, more data are needed from the fossil record. What we know today is that the earliest organisms involved in oxygenic photosynthesis, the cyanobacteria, may have evolved as early as the Archean and diversified in Proterozoic marine and near-shore environments (Knoll et al., 2007). They became the primary source of oxygen, an event that dramatically changed the oceanic and atmospheric chemistry of the Proterozoic and may have contributed to the onset of a major glaciation around 2.3 Ga (Kirschvink and Kopp, 2008). The oxygen rise in the oceans also paved the way for the evolution of the eukaryotes, among which the photosynthetic green algae that may have originated around 1.2-1.3 Ga (Knoll et al., 2007). The photosynthetic eukaryotes derived from streptophytic green algae that successfully colonized the land in the early Middle Palaeozoic are the embryophytes. The first embryophytes remained at a bryophytic grade of complexity until the Silurian when the evolution of the tracheophytes changed the way land plants acquired and transported water to the photosynthetic parts. However, it is not until the Middle to Late Devonian, when they achieved the tree habit, evolved deep roots, and got access to dry upland habitats that tracheophytic land plants are thought to have significantly modified the carbon cycle and climate through the modification of organic carbon fluxes and the enhancement of pedogenesis and continental rock weathering (Algeo and Scheckler, 1998; Berner and Kothavala, 2001; Beerling and Berner, 2005; Strother et al., 2010). With a dramatic drop of atmospheric $\mathrm{CO}_{2}$, this process may have been a major driver of the glaciations recorded in the Late Palaeozoic. This hypothesis was popularized by Algeo et al. (see references in Algeo and Scheckler, 1998). It stimulated studies on Middle to Late Devonian palaeosols (Driese and Mora, 2001; Mintz et al., 2010) and the search for evidence of early trees (Berry and Fairon-Demaret, 2002; Soria and Meyer-Berthaud, 2004; Stein et al., 2007; Giesen and Berry, 2013) and extensive root systems (Hao et al., 2010; Stein et al., 2012; Meyer-Berthaud et al., 2013; Kenrick and Strullu-Derrien, 2014; Morris et al., 2015). It is becoming clear, however, that as early land plants evolved specialized tissues and organs, 
diversified their branching patterns, formed increasingly diverse and complex communities involving other organisms, and extended their spatial distribution on the continents, the way they impacted climates and geochemical cycles became more complex and may have been more progressive than generally presented today (Beerling and Berner, 2005; Coates et al., 2011). The terrestrialization of plants may have even led to counter-intuitive results such as a decoupling between $p \mathrm{CO}_{2}$ and temperatures in the Late Devonian (Le Hir et al., 2011). Documenting the morphological evolution of early land plants, reconstructing their growth habit, inferring their physiological properties, and estimating their ecological needs are thus becoming tasks of interest for a large range of researchers, beyond the strict community of palaeobotanists.

This Special Issue of Review of Palaeobotany and Palynology comprises 18 papers devoted to the terrestrialization of plants. It is split into two volumes, the present one and a second which will be published in early 2016. Collectively, the 18 contributions fulfill six objectives: (i) describing new taxa or complete information on previously known taxa by providing new data on their morphology, growth strategy, and functional biology; (ii) increasing data on the taxonomic composition and palaeogeographical distribution of early land plant assemblages; (iii) discussing the impact of the terrestrialization on marine biotas; (iv) reviewing current evidence for the origin and diversification of the major groups of land plants; ( $v$ ) analyzing the patterns of early land plant diversity dynamics for a better assessment of the factors contributing to taxonomic changes; and (vi) exploring new methods for assessing the occurrence of early land plants in sediments as alternatives to the morphological study of micro- and macro-fossils. The eight contributions of the present volume address the first three objectives.

The primary source of evidence for documenting the earliest land plant assemblages is provided by the palynological record. The paper by Raevskaya et al. (2016) is an important contribution to the knowledge of the palaeophytogeographic distribution of the earliest embryophytes, documenting for the first time the occurrence of profuse and well preserved cryptospore assemblages from Katian (Upper Ordovician) strata in the Siberian palaeocontinent. Raevskaya et al. (2016) describe a cryptospore and trilete spore assemblage recovered from glacial-related deposits of Hirnantian (Late Ordovician) age, confirming that a widespread embryophytic cover was already in place by the end of the Ordovician Period, and that this earliest vegetation was largely unaffected by the onset of glacial conditions in Gondwana. Moreover, the record of trilete spores co-occurring with cryptospores by Rubinstein et al. (2016) supports the existence of taxonomically diverse land plant communities as early as the Late Ordovician, perhaps comprising early vascular plants (Steemans et al., 2009). Servais et al. (2016) present a critical review of models linking oceanic phytoplankton diversity, evolution of early terrestrial ecosystems and changes in atmospheric composition (e.g., $p \mathrm{CO}_{2}, \mathrm{pO}_{2}$ ). The authors conclude that no 'phytoplankton blackout' occurred during Permo-Carboniferous times, and that levels of oceanic primary productivity were high during this time interval, due to increased nutrient run-off into the oceans.

For a long time, the major source of information regarding Devonian plants came from Western Europe and the United States. The record of new taxa from this part of the world is far from being exhausted as demonstrated by the recent discovery of the euphyllophytic genus Armoricaphyton Strullu-Derrien et al. in a Pragian locality of France (Gerrienne et al., 2011; Strullu-Derrien et al., 2014). Gerrienne and Gensel (2016) detail the primary vascular architecture and branching pattern of this diminutive plant producing wood. They show that primary growth in Armoricaphyton is consistent with the phases called "epidogenetic" and "menetogenetic" of Eggert's (1961) ontogenetic model.

The record of Devonian plant taxa from Australia is slowly expanding and contributes to better understand the eventual specificity of the diversity dynamics in eastern Gondwana. Meyer-Berthaud et al.
(2016) report the occurrence, in a Middle to early Late Devonian locality of New South Wales, of Lepidosigillaria-type lycopsids and specimens referable to the genus Tetraxylopteris Beck emend. Hammond and Berry. The latter represents the first known occurrence of aneurophytalean progymnosperms in Australia. The vegetative specimens of Tetraxylopteris show highly dissected ultimate appendages suggestive of a new species.

The numerous investigations conducted in Middle and Late Devonian deposits of China greatly changed our views on the morphological diversity of two major groups of plants of this time interval, the "cladoxylopsid-iridopterid complex" of euphyllophytes which are characterized by their dissected vascular anatomy, and the lycopsids characterized by their uni-nervate type of leaves and closely associated sporangia. In western countries, the Middle Devonian cladoxylopsids described to date share a tree-type of habit consisting of a trunk bearing closely inserted branches that divide dichotomously and in a single plane (i.e. digitately). A tree-habit has not yet been demonstrated in the cladoxylopsids from China and branching in the latter taxa is generally pseudomonopodial. This is the case for Panxia Wang and Berry, a Middle Devonian genus from Yunnan tentatively assigned to the Cladoxylopsida by its authors (Wang and Berry, 2006). Xue et al. (2016) provide the first detailed anatomical description of a branching stem of Panxia lacking secondary tissues. They show that this specimen shares anatomical features with members of both the Cladoxylopsida and the Iridopteridales, supporting the idea that the systematic relationships within this complex of plants are far from being resolved. In a next chapter of this volume, Meng et al. (2016) describe new Late Devonian material of the arborescent lycopsid Sublepidodendron grabaui (Sze) Wang and Xu and complete the reconstruction of this widely distributed species of South China. They demonstrate the occurrence of pseudomonopodial divisions in branches and confirm the monosporangiate nature of the cones. The latter character supports the classification of the Sublepidodendraceae in the suborder Dichostrobiles DiMichele and Bateman, 1996 (Isoëtales) whose diversity peaked in Carboniferous and Permian times.

Finally, Orlova et al. (2016) provide a thorough review of the occurrence and composition of a succession of Late Devonian plant assemblages collected in North Timan and housed in the collections of three Russian Institutes. They make available information from hardly accessible literature and clarify the stratigraphic context of these findings. They have themselves critically reviewed the systematic affinities of some of the specimens. Palaeodiversity analyses should greatly benefit from this work.

\section{Acknowledgments}

This Special Issue is produced under the auspices of the French Agence Nationale de la Recherche. As guest editors, we would like to thank all the authors who accepted to participate to this volume and the reviewers for their careful and constructive recommendations.

\section{References}

Algeo, T.J., Scheckler, S.E., 1998. Terrestrial-marine teleconnections in the Devonian: links between the evolution of land plants, weathering processes, and marine anoxic events. Philos. Trans. R. Soc. Lond. B 353, 113-130.

Beerling, D.J., Berner, R.A., 2005. Feedbacks and the coevolution of plants and atmospheric $\mathrm{CO}_{2}$. Proc. Natl. Acad. Sci. U. S. A. 102, 1302-1305.

Berner, R.A., 2006. GEOCARBSULF: a combined model for Phanerozoic atmospheric $\mathrm{O}_{2}$ and $\mathrm{CO}_{2}$. Geochim. Cosmochim. Acta 70, 5653-5664.

Berner, R.A., Kothavala, Z., 2001. GEOCARB III: a revised model of atmospheric $\mathrm{CO}_{2}$ over Phanerozoic time. Am. J. Sci. 301, 182-204.

Berry, C.M., Fairon-Demaret, M., 2002. The architecture of Pseudosporochnus nodosus Leclercq et Banks: a Middle Devonian cladoxylopsid from Belgium. Int. J. Plant Sci. 163, 699-713.

Coates, J.C., Moody, L.A., Saidi, Y., 2011. Plants and the Earth system - past events and future challenges. New Phytol. 189, 370-373.

DiMichele, W.A., Bateman, R.M., 1996. The rhizomorphic lycopsids: a case-study in paleobotanical classification. Syst. Bot. 21, 535-552 
Donnadieu, Y., Goddéris, Y., Ramstein, G., Nédélec, A., Meert, J., 2004. A 'Snowball Earth' climate triggered by continental break-up through changes in runoff. Nature 428 303-306.

Driese, S.G., Mora, C.I., 2001. Diversification of Siluro-Devonian plant traces in paleosols and influence on estimates of paleoatmospheric $\mathrm{CO}_{2}$ levels. In: Gensel, P.G. Edwards, D. (Eds.), Plants Invade the Land. Columbia Univ. Press, New York, pp. 237-253.

Eggert, D.A., 1961. The ontogeny of Carboniferous arborescent Lycopsida. Palaeontographica B 108, 43-92.

Gerrienne, P., Gensel, P.G., 2016. New data about anatomy, branching, and inferred growth patterns in the Early Devonian plant Armoricaphyton chateaupannense, Montjean-sur-Loire, France. Rev. Palaeobot. Palynol. 224, 38-53.

Gerrienne, P., Gensel, P.G., Strullu-Derrien, C., Lardeux, H., Steemans, P., Prestianni, C., 2011. A simple type of wood in two Early Devonian plants. Science 333, 837-837.

Giesen, P., Berry, C.M., 2013. Reconstruction and growth of the early tree Calamophyton (Pseudosporochnales, Cladoxylopsida) based on exceptionally complete specimen from Lindlar, Germany (Mid-Devonian): organic connection of Calamophyton branches and Duisbergia trunks. Int. J. Plant Sci. 174, 665-686.

Goddéris, Y., Donnadieu, Y., Le Hir, G., Lefebvre, V., Nardin, E., 2014. The role of palaeogeography in the Phanerozoic history of atmospheric $\mathrm{CO}_{2}$ and climate. Earth-Sci. Rev. 128, 122-138.

Haig, D., 2008. Homologous versus antithetic alternation of generations and the origin of sporophytes. Bot. Rev. 74, 395-418.

Hao, S., Xue, J., Guo, D., Wang, D., 2010. Earliest rooting system and root-shoot ratio from a new Zosterophyllum plant. New Phytol. 185, 217-225.

Kenrick, P., Strullu-Derrien, C., 2014. The origin and early evolution of roots. Plant Physiol. $166,570-580$

Kenrick, P., Wellman, C.H., Schneider, H., Edgecombe, G.D., 2012. A timeline for terrestrialization: consequences for the carbon cycle in the Palaeozoic. Philos. Trans. R. Soc. Lond. B 367, 519-536.

Kirschvink, J.L., Kopp, R.E., 2008. Palaeoproterozoic ice houses and the evolution of oxygen-mediating enzymes: the case for a late origin of photosystem II. Philos. Trans. R. Soc. Lond. B 363, 2755-2765.

Knoll, A.H., Summons, R.E., Waldbauer, J.R., Zumberger, J.E., 2007. The geological succession of primary producers in the oceans. In: Falkowski, P.G., Knoll, A.H (Eds.), Evolution of Primary Producers in the Sea. Elsevier Acad. Press, Burlington, MA, USA, pp. 133-162.

Le Hir, G., Donnadieu, Y., Goddéris, Y., Meyer-Berthaud, B., Ramstein, G., Blakey, R.C., 2011. The climate change caused by the land plant invasion in the Devonian. Earth Planet. Sci. Lett. 310, 203-212.

Meng, M.C., Liu, L., Wang, D.M., Yao, J.X., 2016. Growth architecture and microsporangiate strobilus of Sublepidodendron grabaui (Lycopsida) from the Late Devonian of South China. Rev. Palaeobot. Palynol. 224, 83-93.

Meyer-Berthaud, B., Decombeix, A.-L., Ermacora, X., 2013. Archaeopterid root anatomy and architecture: new information from permineralized specimens of Famennian age from Anti-Atlas (Morocco). Int. J. Plant Sci. 174, 364-381.

Meyer-Berthaud, B., Decombeix, A.-L., Dunstone, R., Gerrienne, P., Momont, N., Young, G., 2016. Tetraxylopteris Beck emend. Hammond and Berry (2005), the first aneurophytalean genus recorded in Australia. Rev. Palaeobot. Palynol. 224, 54-65.
Mintz, J.S., Driese, S.G., White, J.D., 2010. Environmental and ecological variability of Middle Devonian (Givetian) forests in Appalachian basin paleosols, New York, United States. Palaios 25, 85-96

Morris, J.L., Leake, J.R., Stein, W.E., Berry, C.M., Marshall, J.E.A., Wellman, C.H., Milton, J.A., Hillier, S., Mannolini, F., Quirk, J., Beerling, D.J., 2015. Investigating Devonian trees as geo-engineers of past climates: linking palaeosols to palaeobotany and experimental geobiology. Palaeontology 58, 787-801.

Orlova, O.A., Jurina, A.L., Snigirevsky, S.M., 2016. Late Devonian plant communities of North Russia. Rev. Palaeobot. Palynol. 224, 94-107.

Qiu, Y.-L., Taylor, A.B., McManus, H.A., 2012. Evolution of the life cycle in land plants. J. Syst. Evol. 50, 171-194.

Raevskaya, E., Dronov, A., Servais, T., Wellman, C.H., 2016. Cryptospores from the Katian (Upper Ordovician) of the Tungus basin: the first evidence for early land plants from the Siberian palaeocontinent. Rev. Palaeobot. Palynol. 224, 4-13.

Rubinstein, C.V de la Puente, G.S., Delabroye, A. Astini, R.A. 2016. The palynological record across the Ordovician/Silurian boundary in the Cordillera Oriental, Central Andean Basin, northwestern Argentina. Rev. Palaeobot. Palynol. 224, 14-25.

Servais, T., Martin, R.E., Nützel, A., 2016. The impact of the 'terrestrialisation process' in the Late Palaeozoic: pCO2, pO2, and the 'phytoplankton blackout'. Rev. Palaeobot. Palynol. 224, 26-37.

Soria, A., Meyer-Berthaud, B., 2004. Tree fern growth strategy in the Late Devonian cladoxylopsid species Pietzchia levis from the study of its stem and root system. Am. J. Bot. 91, 10-23.

Steemans, P., Le Hérissé, A., Melvin, J., Miller, M.A., Paris, F., Verniers, J., Wellman, C.H., 2009. Origin and radiation of the earliest vascular land plants. Science 324, 353-353.

Stein, W.E., Mannolini, F., Hernick, L.V., Landing, E., Berry, C.M., 2007. Giant cladoxylopsid trees resolve the enigma of the Earth's earliest forest stumps at Gilboa. Nature 446, 904-907.

Stein, W.E., Berry, C.M., Hernick, LV. Mannolini, F., 2012. Surprisingly complex community discovered in the mid-Devonian fossil forest at Gilboa. Nature 483, 78-81.

Strother, P.K., Servais, T., Vecoli, M., 2010. The effects of terrestrialization on marine ecosystems: the fall of $\mathrm{CO}_{2}$. In: Vecoli, M., Clément, G., Meyer-Berthaud, B. (Eds.), The Terrestrialization Process: Modelling Complex Interactions at the Biospheregeosphere Interface. Geol. Soc. London Special Publication 339, pp. 37-48.

Strullu-Derrien, C., Kenrick, P., Tafforeau, P., Cochard, H., Bonnemain, J.L., Le Hérissé, A., Lardeux, H., Badel, E., 2014. The earliest wood and its hydraulic properties documented in c. 407-million-year-old fossils using synchrotron microtomography. Bot. J. Linn. Soc. $175,423-437$.

Taylor, W.A., Strother, P.K., 2009. Ultrastructure, morphology, and topology of Cambrian palynomorphs from the Lone Rock Formation, Wisconsin, USA. Rev. Palaeobot. Palynol. 153, 296-309.

Wang, Y., Berry, C.M., 2006. Morphology of a non-pseudosporochnalean cladoxylopsid from the Middle Devonian of Yunnan, South China. Paleoworld 15, 54-67.

Wellman, C.H., 2010. The invasion of the land by plants: when and where? New Phytol. 188, 306-309.

Xue, J., Huang, P., Wang, D.M., Wang, Q., Hao, S.G., 2016. Anatomy of the Middle Devonian cladoxylopsid Panxia gabata Y. Wang et Berry from Yunnan Province, southwestern China. Rev. Palaeobot. Palynol. 224, 66-82. 